Research article

\title{
BLO0D GASES, ACID-BASE STATUS AND PLASMA LACTATE CONCENTRATIONS IN CALVES WITH RESPIRATORY DISEASES
}

\author{
ŠOLTÉSOVÁ Helena, NAGY Oskar*, TÓTHOVÁ Csilla, PAULÍKOVÁ Iveta, \\ SEIDEL Herbert
}

University of Veterinary Medicine and Pharmacy, Komenského 73, 04181 Košice, Slovak Republic

(Received 26 $6^{\text {th }}$ March; Accepted $9^{\text {th }}$ September 2014)

\begin{abstract}
The purpose of this study was to evaluate in calves the effects of respiratory diseases of various severities on blood gases, acid-base balance and plasma lactate concentration. We included in the study 128 calves with clinical signs of various severities and outcomes of respiratory disorders. The age of the calves ranged from 1 to 12 months. According to the clinical findings, course of the disease and time of blood collection, the sick calves were divided into three groups: RD $1(n=34)$ - calves with moderate clinical signs; RD $2(n=73)$ - calves with severe respiratory symptoms and RD $3(n=21)-$ calves with severe respiratory symptoms and died within 48 hours after blood sampling. Into the study we also included one group of 28 clinically healthy calves. In the arterial blood we evaluated: blood $\mathrm{pH}$, partial pressure of carbon dioxide $-\mathrm{pCO}_{2}$, partial pressure of oxygen $-\mathrm{pO}_{2}$, concentration of actual bicarbonate $-\mathrm{HCO}_{3}$, base excess $-\mathrm{BE}$, and saturation of hemoglobin by oxygen $-\mathrm{O}_{2}$-sat. The concentration of lactate was determined in the blood plasma. Significant effects of health status and severity of respiratory diseases were recorded in all the evaluated variables. Marked hypoxemia and hypercapnia were found in calves with severe respiratory disorders and in animals that died within 48 hours after blood collection. In most calves, the acid- base changes were characterized as compensated respiratory acidosis. The highest mean lactate values were recorded in calves that died within 48 hours after blood sampling. The presented results suggest the usefulness of the analysis of blood gases and acid-base status in the evaluation and prognosis of various degrees and severity of respiratory diseases in calves, and in monitoring the patient response to treatment. Although plasma lactate analysis is less consistent with the severity of respiratory diseases, it might be helpful in the indication of an untreatable stage of the disease and upcoming death.
\end{abstract}

Key words: acid-base; blood gases; calves; lactate; respiratory disease.

\section{INTRODUCTION}

Despite prophylactic measures, respiratory diseases remain the major cause of economic losses in bovine species. Mortality, diminished zootechnical performances Corresponding author: e-mail: onagy@uvm.sk 
caused by irreversible pulmonary lesions, and high cost price of therapeutic interventions explain the enormous economical impact of respiratory diseases [1]. Even if there is a lot of knowledge about the etiology of bovine respiratory diseases (BRD), the therapeutic effect is often unsatisfactory. Early identification and treatment of sick animals is considered to be the key to success in outbreaks of BRD, and early and accurate diagnosis are a prerequisite for successful treatment. The inherent time lag in many laboratory tests necessitates the practitioner often to act on their initial clinical impression, but laboratory confirmation and monitoring can be essential for adjusting the treatment and preventative protocols [2]. Although various forms of calves' respiratory diseases are known, their clinical manifestation is frequently less differentiated. A detailed examination of the respiratory tract in ruminants provides a great deal of diagnostic information. However, there are situations in which the diagnosis remains in question, and inaccurate diagnosis may lead to unnecessary treatment delays, and additional expense or herd mortality [3]. Clinical examination represents only the starting point in diagnosing the lung diseases resulting in symptomatic diagnosis and only partial evaluation of disease severity [4]. However, by clinical examination, it is difficult or even impossible to assess morphological and functional changes in a sufficient manner. Therefore, there is a need for other additional specific clinical examination protocols [5].

Because of the important role of the respiratory system in gas exchange, respiratory diseases may seriously affect body functions, particularly tissue oxygenation, elimination of carbon dioxide, as well as acid-base balance. In calves suffering from respiratory syndrome, published data indicate a various degree of changes in blood gases and disturbances of acid-base balance [6,7]. The analysis of blood gases (BG) of arterial blood is an important tool in the evaluation of lung dysfunctions [8]; it is the base of respiratory functional diagnosis [7]. Several authors incline to the opinion that particularly partial pressure of oxygen $\left(\mathrm{pO}_{2}\right)$ values offer the most sensitive evaluation of the presence and severity of respiratory disease $[9,10]$. Compared with the partial pressure of carbon dioxide $\left(\mathrm{pCO}_{2}\right), \mathrm{pO}_{2}$ changes even in cases of mild lung affection and disturbance in the alveolar gas exchange. Occurrence of respiratory acidosis is caused by global respiratory insufficiency [11] and possible decrease in blood $\mathrm{pH}$ occurs in this case due to an increase in $\mathrm{pCO}_{2}$ in the arterial blood and failure of renal regulatory function. Because over 95 per cent of oxygen delivery to tissues is by oxyhemoglobin, the oxygen hemoglobin saturation is of the greatest clinical significance. Decreased delivery to the brain or heart can lead to collapse, and decreased delivery to other tissues leads to lactic acidosis and metabolic abnormalities [12]. However, there are only few data about the effects of hypoxia on blood lactate levels and, consequently, hypoxic lactacidemia and changes in acid-base balance in calves suffering from respiratory diseases [13-16].

The aim of this work was to investigate the effects of etiologically undifferentiated respiratory diseases in calves on lung functions and the degree of compensation of respiratory disturbances by metabolic pathways of the acid-base homeostasis in calves. 
At the same time we studied the effect of generalized tissue hypoxia on blood plasma levels of lactate and its potential involvement in the changes of the acid-base balance. In calves, we evaluated the association between blood gases, acid-base status, lactate levels and severity of clinical sings of respiratory diseases.

\section{MATERIALAND METHODS}

\section{Animals and clinic al examination}

In this study were included 128 calves with clinical signs of various severities and outcome of respiratory disorders. The calves were of a Low-land black spotted breed, Slovak spotted breed, or their crossbreeds. The age of the calves ranged from 1 to 12 months. The evaluated animals were submitted to the Clinic for Ruminants of the University of Veterinary Medicine and Pharmacy in Kosice by private veterinarians from conventional dairy farms. At the clinic, the calves were housed individually, fed twice a day depending on their age (milk replacer, grass-legume hay, concentrates), with free access to water. After the arrival to the clinic, prior to blood collection and treatment, all calves were thoroughly examined using physical clinical examination procedures oriented to the examination of the general health state, and then specially to the respiratory system [17]. Following clinical examination, we included only calves without any other disease, which might affect the investigated indices. The main criteria for clinical assessment of the severity of respiratory disorders were as follows:

- general health state - case history, behavior, food intake, body temperature, body condition

- clinical fndings on the respiratory system were obtained by inspection (breathing rate and type, discharge from nostrils, signs of dyspnoea, cough, additional respiratory movements) and by auscultation (type, extent, character, and intensity of respiratory sounds, adventitious respiratory sounds)

Treatment of calves after the clinical examination was performed according to the clinical signs based on the use of antibiotics combined with non-steroidal antiinflammatory drugs and bronchodilators. According to the clinical findings, course of the disease and time of blood collection, the sick calves were divided into three groups:

RD 1 ( $\mathrm{n}=34)$ - calves with moderate clinical signs (alert, good appetite, increased breathing rate, induced single cough, dyspnoea, small amount of mucous mucopurulent discharge). Calves with improved health state after the treatment and returned back to the farm.

RD 2 ( $\mathrm{n}=73$ ) - calves with severe respiratory symptoms (depression, reluctance to rise, loss of appetite, droopy ears, copious purulent nasal discharge, severe dyspnoea, labored breathing, open mouth breathing, extended head and neck, spontaneous repeated cough, stridor, wheezes or crackles on auscultation). Forty six calves in 
spite of the treatment died, other were euthanized, 27 animals were recommended for culling from the herd because of poor response to treatment and unfavorable prognosis.

RD 1+2 $(\mathrm{n}=107)$ - sum of calves with respiratory disease in groups RD 1 and RD 2

RD $3(n=21)$ - calves with severe respiratory symptoms as presented in group RD 2 on day of arrival, but died less than 48 hours after clinical examination and blood sampling.

In order to compare the obtained results of sick animals with calves without respiratory signs, into the study we included one group of 28 clinically healthy calves of the same age and breed.

\section{Blood sample collection}

After the clinical examination and assessment of the severity of the disease blood samples were collected by direct puncture of a. axillaris into $1 \mathrm{ml}$ plastic syringes (Radiometer Copenhagen, Denmark). The dead space of the syringe was filled with sodium heparin solution at a concentration of 500 I.U. per ml of blood. The samples were analyzed within $15 \mathrm{~min}$ after the collection with a blood gas analyzer ABL 5 (Radiometer Copenhagen). The following indices were evaluated: blood $\mathrm{pH}$, partial pressure of carbon dioxide $-\mathrm{pCO}_{2}$, partial pressure of oxygen $-\mathrm{pO}_{2}$, concentration of actual bicarbonate $-\mathrm{HCO}_{3}^{-}$, base excess $-\mathrm{BE}$, and saturation of hemoglobin with oxygen $-\mathrm{O}_{2}$-sat. The results were corrected for body temperature. Blood samples for the determination of plasma lactate concentration were collected by direct puncture of $\mathrm{v}$. jugularis. Sodium fluoride was used as a stabilizer for the prevention of glycolysis and production of lactate. Blood tubes were centrifuged $30 \mathrm{~min}$. at 3000 r.p.m. within 30 minutes after blood collection. The separated plasma was stored at $-20^{\circ} \mathrm{C}$ until analyzed. Lactate concentration was analyzed by an enzymatic-photometric method with the use of an automatic biochemical analyser ALIZÉ (Lisabio, France) and commercial test kits (BioMérieux).

\section{Statistic al analyses}

Arithmetic means (x) and standard deviations (SD) for each evaluated variable and calculated using descriptive statistical procedures. One way analysis of variance (ANOVA) was used for the analysis of the significance of the differences $(\mathrm{P})$ in means between the groups of sick and healthy animals. Relationships between the concentrations of lactate and variables of acid-base balance and blood gases in the evaluated groups of sick calves were calculated by linear regression and Pearson correlation test, including the correlation coefficient $(\mathrm{R})$ and significance of correlation (P). All statistical analyses were performed using the computer programme GraphPad Prism V5.02 (GraphPad Software Inc., California, USA). 


\section{RESULTS}

The results found in the evaluated groups of calves are presented in Tables 1 and 2 including means, standard deviations and significances of the differences in the mean values between the evaluated groups of animals. Analysis of the distribution of the individual plasma lactate concentrations in calves and regression analysis between lactate values and $\mathrm{pO}_{2}$ in sick calves are presented in Figures 1 and $2 \mathrm{~A}-\mathrm{C}$.

Table 1. Blood gases, acid-base status and plasma lactate concentrations in the evaluated groups of calves (mean $\pm \mathrm{SD}$ )

\begin{tabular}{lccccc}
\hline \multirow{2}{*}{ Variables } & \multicolumn{4}{c}{ Group of calves } & P \\
\cline { 2 - 5 } & Healthy & RD 1 & RD 2 & RD 3 & value \\
\hline $\mathrm{pH}$ & $7.42 \pm 0.03^{\mathrm{A}}$ & $7.43 \pm 0.03^{\mathrm{aB}}$ & $7.41 \pm 0.04^{\mathrm{AC}}$ & $7.36 \pm 0.06^{\mathrm{ABC}}$ & $<0.001$ \\
$\mathrm{pO}_{2}(\mathrm{kPa})$ & $11.1 \pm 0.7^{\mathrm{ABC}}$ & $9.0 \pm 1.0^{\mathrm{ADE}}$ & $6.4 \pm 1.5 \mathrm{~B}^{\mathrm{DF}}$ & $4.6 \pm 1.2^{\mathrm{BCEF}}$ & $<0.001$ \\
$\mathrm{O}_{2}$-sat $\left.^{\mathrm{Sa}} \%\right)$ & $96.0 \pm 0.8^{\mathrm{ABC}}$ & $93.2 \pm 2.3^{\mathrm{ADE}}$ & $79.4 \pm 13.6^{\mathrm{BDF}}$ & $60.1 \pm 18.0^{\mathrm{BCEF}}$ & $<0.001$ \\
$\mathrm{pCO}_{2}(\mathrm{kPa})$ & $5.6 \pm 0.3^{\mathrm{AB}}$ & $5.8 \pm 0.6^{\mathrm{CD}}$ & $6.8 \pm 1.2^{\mathrm{ACx}}$ & $7.8 \pm 1.5^{\mathrm{xBD}}$ & $<0.001$ \\
$\mathrm{HCO}_{3}^{-}(\mathrm{mmol} / \mathrm{l})$ & $26.3 \pm 1.8^{\mathrm{AB}}$ & $28.3 \pm 2.6^{\mathrm{xC}}$ & $31.6 \pm 4.8^{\mathrm{AC}}$ & $32.1 \pm 4.1^{\mathrm{xB}}$ & $<0.001$ \\
$\mathrm{BE}(\mathrm{mmol} / \mathrm{l})$ & $2.1 \pm 1.7^{\mathrm{axA}}$ & $4.3 \pm 2.3^{\mathrm{a}}$ & $5.9 \pm 3.8^{\mathrm{A}}$ & $5.2 \pm 3.7^{\mathrm{x}}$ & $<0.001$ \\
lactate $(\mathrm{mmol} / \mathrm{l})$ & $0.85 \pm 0.26^{\mathrm{A}}$ & $0.88 \pm 0.26^{\mathrm{B}}$ & $1.20 \pm 0.41^{\mathrm{C}}$ & $2.63 \pm 1.88^{\mathrm{ABC}}$ & $<0.001$ \\
\hline
\end{tabular}

a, $x, A-F-$ means with common superscripts in rows differ significatly at a level $-\mathrm{a}-\mathrm{P}<0.05$; $\mathrm{x}-\mathrm{P}<0.01 ; \mathrm{A}-\mathrm{F}-\mathrm{P}<0.001$

Table 2. Regression analysis of the relationship between the concentrations of plasma lactate and variables of blood gases and acid-base balance in the evaluated groups of calves suffering from respiratory diseases

\begin{tabular}{cccccccc}
\hline $\begin{array}{c}\text { Group of } \\
\text { calves }\end{array}$ & $\mathbf{p H}$ & $\begin{array}{c}\mathbf{p O} \\
\mathbf{( k P a )}\end{array}$ & $\begin{array}{c}\mathbf{p C O}_{2} \\
\mathbf{( k P a )}\end{array}$ & $\begin{array}{c}\mathbf{0}_{2} \text {-sat } \\
\mathbf{( \% )}\end{array}$ & $\begin{array}{c}\mathbf{H C O}_{3}^{-} \\
(\mathbf{m m o l} / \mathbf{l})\end{array}$ & $\begin{array}{c}\mathbf{B E} \\
(\mathbf{m m o l} / \mathbf{l})\end{array}$ \\
\hline \multirow{2}{*}{$\mathrm{RD} 1+2$} & $\mathrm{R}$ & -0.2361 & -0.5346 & 0.2218 & -0.5653 & 0.1143 & 0.0412 \\
& $\mathrm{P}$ & $<0.05$ & $<0.001$ & $<0.05$ & $<0.001$ & n.s. & n.s. \\
\multirow{2}{*}{ RD 1 } & $\mathrm{R}$ & 0.0069 & 0.1622 & -0.1636 & 0.1378 & -0.1193 & -0.1674 \\
& $\mathrm{P}$ & n.s. & n.s. & n.s. & n.s. & n.s. & n.s. \\
\multirow{2}{*}{ RD 2 } & $\mathrm{R}$ & -0.1791 & -0.5140 & 0.0852 & -0.5519 & -0.0480 & -0.0730 \\
& $\mathrm{P}$ & n.s. & $<0.001$ & n.s. & $<0.001$ & n.s. & n.s. \\
\multirow{2}{*}{ RD 3 } & $\mathrm{R}$ & -0.0860 & -0.5137 & -0.2431 & -0.5106 & -0.4273 & -0.4405 \\
& $\mathrm{P}$ & n.s. & $<0.05$ & n.s. & $<0.05$ & n.s. & $<0.05$ \\
\hline
\end{tabular}

$\mathrm{R}$ - correlation coefficient; $\mathrm{P}$-correlation significance 
In all the evaluated parameters highly significant effect of the health state and severity of respiratory diseases in calves was recorded (Table 1; $\mathrm{P}<0.001$ ). Hypoxemia with significantly lower $\mathrm{pO}_{2}$ and $\mathrm{O}_{2}$-sat in comparison to healthy animals was found in all groups of sick calves $(\mathrm{P}<0.001)$. Marked significant differences in the means of $\mathrm{pO}_{2}$ $(2.6 \mathrm{kPa})$ and $\mathrm{O}_{2}$-sat $(13.8 \%)$ were recorded between the moderate and more severely affected animals (group RD 1 and 2; $\mathrm{P}<0.001$ ). Significantly more serious hypoxemia with the lowest mean values of $\mathrm{pO}_{2}$ and $\mathrm{O}_{2}$-sat ( $4.6 \mathrm{kPa}$ and $60.1 \%$, respectively) was found in animals in group $\mathrm{RD} 3$. These values were as low as those usually recorded in the venous blood. The mean values of $\mathrm{pCO}_{2}$, as well as blood $\mathrm{pH}$ and bicarbonates did not differ significantly between the healthy and moderately sick calves (group RD 1). Hypercapnia and significantly higher mean values of $\mathrm{pCO}_{2}$ were found in animals with severe respiratory clinical signs $(\mathrm{P}<0.001)$, as well as in animals in group RD 3 $(\mathrm{P}<0.001)$ compared with healthy animals. The differences between the mean values of $\mathrm{pCO}_{2}$ of these two groups of calves were significant $(\mathrm{P}<0.01)$. The highest mean value of $\mathrm{pCO}_{2}$ was recorded in calves of group RD 3. In group RD 1, only 9 of 34 calves suffered from global respiratory insufficiency, in groups RD 2 and RD 3 global respiratory insufficiency was found in 55 of 74 and 19 of 21 calves, respectively. In all groups of calves, the mean blood $\mathrm{pH}$ values were within the reference interval. Significantly lower mean blood $\mathrm{pH}$ in comparison to healthy animals and calves of group RD 1 and 2 was found in calves of group RD $3(\mathrm{P}<0.001)$. The mean blood $\mathrm{pH}$ in group RD 2 was significantly lower than in calves in group RD $1(\mathrm{P}<0.05)$. Blood $\mathrm{pH}$ lower than 7.35 was recorded in group RD 2 in 4 of 73 animals (5.5\%) and in 7 of 21 calves in group $\mathrm{RD} 3(33.3 \%)$. The mean values of $\mathrm{HCO}_{3}$ and $\mathrm{BE}$ were higher in all groups of sick animals. The significantly highest values were recorded in animals of groups $\mathrm{RD} 2$ and $\mathrm{RD} 3(\mathrm{P}<0.001)$. Even in calves suffering from less severe respiratory clinical signs the mean values of $\mathrm{HCO}_{3}^{-}$and $\mathrm{BE}$ were higher than in healthy ones ( $\mathrm{P}>0.05$ and $\mathrm{P}<0.05$, respectively).

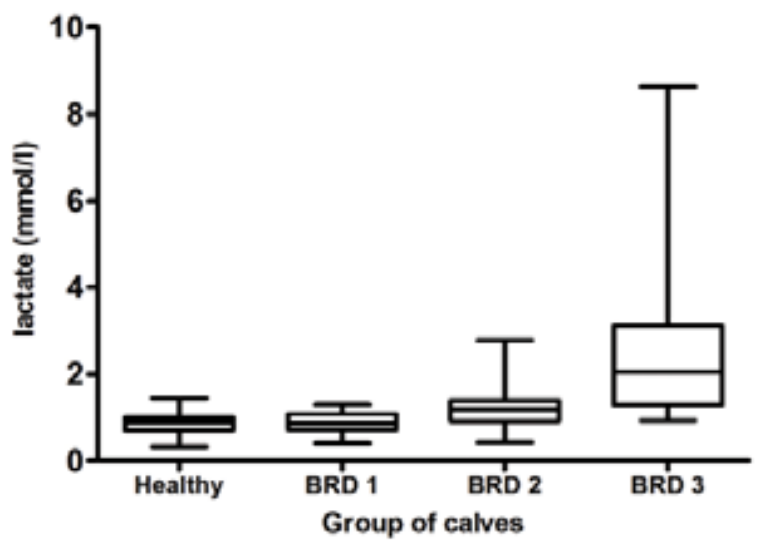

Figure 1. Distribution of the individual results of plasma lactate concentrations in the evaluated groups of calves. The plot shows the median (line within the box), 25th and 75th percentiles (box), minimal and maximal values (whiskers) 
The mean values and medians of plasma lactate were similar in healthy and less severely sick calves, higher values were found in calves suffering from severe respiratory diseases (Figure 1). The significantly highest concentrations of lactate were found in calves that died within 48 hours after blood sampling (group RD 3; $\mathrm{P}<0.001$ ). The highest lactate concentration recorded in this group of calves was $8.63 \mathrm{mmol} / \mathrm{l}$ and in 11 animals (52.4\%) the lactate levels were higher than $2.0 \mathrm{mmol} / 1$. In group RD 2 only three calves of 73 were found with higher lactate concentrations than $2.0 \mathrm{mmol} / \mathrm{l}$.
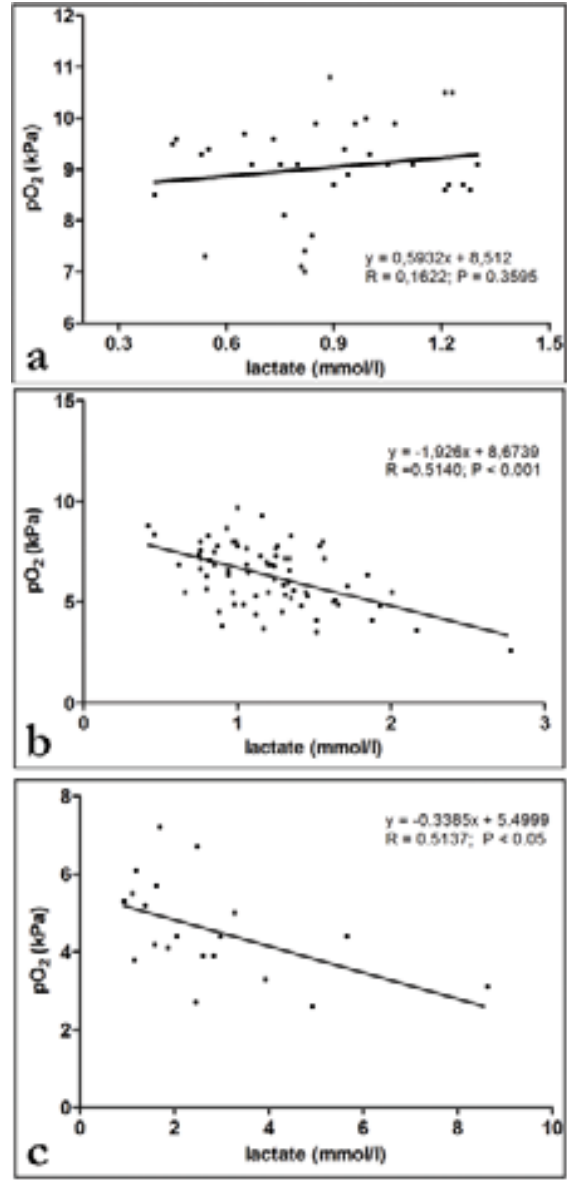

Figure 2A-C. Correlation and regression analysis between the blood $\mathrm{pO}_{2}$ and plasma lactate concentrations in calves of group RD 1 (A), RD 2 (B) and RD 3 (C)

Analysis of the relationships between plasma lactate concentrations and the variables of blood gases and acid-base balance in animals suffering from respiratory diseases (Table 2) showed significantly higher negative correlations between the levels of plasma lactate and $\mathrm{pO}_{2}$ and $\mathrm{O}_{2}$-sat in all sick animals (group $\mathrm{RD} 1+2 ; \mathrm{P}<0.001$ ), as well as in calves that died within 48 hour after blood sampling (Figure 1C; $\mathrm{P}<0.05$ ). The analysis performed according to the severity of the respiratory signs showed 
differences in the correlations between groups $\mathrm{RD} 1$ an $\mathrm{RD} 2$, with highly significant correlations only in group $\mathrm{RD} 2$ (Figure $2 \mathrm{~A}-\mathrm{B} ; \mathrm{P}<0.001$ ). In sick calves without differentiation of the severity of the disease (group RD 1+2), the concentrations of lactate also correlated with blood $\mathrm{pH}$ (negative; $\mathrm{P}<0.05$ ) and $\mathrm{pCO}_{2}$ (positive; $\mathrm{P}<0.05$ ). In calves that died within 48 hours after blood sampling, the lactate levels significantly negatively correlated with the values of $\mathrm{BE}(\mathrm{P}<0.05)$. No significant correlations were recorded between plasma lactate and variables of blood gases and acid-base balance in calves suffering from moderate clinical signs of respiratory diseases (group RD 1).

\section{DISCUSSION}

Respiratory diseases are the most prevalent diseases in young cattle. Prophylactic and therapeutic measures, reduced growth performance and mortality due to respiratory diseases lead to considerable economic losses [8]. Respiratory diseases in calves are associated with a wide scale of pathological findings in lung parenchyma, as well as in the respiratory pathways. In many cases, it is difficult to estimate the severity of lung tissue damage only by clinical examination, which may lead to delayed treatment and doubtful prognosis. Because clinical signs are frequently uniform, diagnosis should determine the site, severity, and intensity of lung tissue lesions within the course of the respiratory disease [19]. Functional diagnostics of the lungs widens the possibilities of respiratory tract diagnosing in calves [7]. Blood gas analysis as a ,gold standard“" allows the qualitative and quantitative assessment of both metabolic and respiratory acid-base problems, including the interrelationship between ventilation, oxygenation, and metabolic condition, enabling therapeutic decisions to be made. It is useful for following trends in animals, as well as for assessing the severity of a disease [20]. In the pathogenesis of respiratory diseases in calves, disturbances in ventilation, pulmonary diffusion, pulmonary hemodynamics and/or ventilation-perfusion mismatching may result in decreased arterial $\mathrm{O}_{2}$ levels. An increasing partial pressure of $\mathrm{CO}_{2}$, as is often observed in ventilatory disturbances or in a disturbed ventilatory distribution, causes respiratory acidosis. Because of the compensatory mechanisms of respiratory (hyperventilation) and circulatory systems (increased heart rate and minute volume), an adequate total oxygen uptake can be maintained despite respiratory insufficiency until shortly before death [21]. A consequence of alveolar hypoventilation and hypoxia is hypoxic pulmonary vasoconstriction as a regulatory mechanism in alveolar hypoventilation by which blood flow is diverted from poorly ventilated areas to better ventilated alveolar regions. This mechanism aims to improve the ventilation/perfusion ratio in the case of atelectases. Although this mechanism of blood redistribution is beneficial in the case of localized alveolar hypoxia, it may have serious consequences on the right heart work when hypoxia is generalized, such as in animals with severe diffuse lung diseases [22].

In our study, the results showed marked relationships between the severity of respiratory diseases and values of $\mathrm{pO}_{2}$ and $\mathrm{O}_{2}$-sat. The changes observed in sick calves 
correlated with the clinical picture by decreasing values even in mild cases. In calves with a severe respiratory syndrome, about half of the animals showed values of $\mathrm{pO}_{2}$ and $\mathrm{O}_{2}$-sat, common for venous blood. On the other hand, increasing values of $\mathrm{pCO}_{2}$ were recorded only in calves with severe clinical symptoms. While some authors reported in calves suffering from clinically non-differentiated bronchopneumonia a decrease in $\mathrm{pO}_{2}$ values together with an increase in $\mathrm{pCO}_{2}[6,7]$, other authors in calves with chronic bronchopneumonia recorded a marked decrease in $\mathrm{pO}_{2}$ values and $\mathrm{pCO}_{2}$ values insignificantly lower than in healthy animals [23]. The lower $\mathrm{pCO}_{2}$ values are explained by higher respiratory rates and hyperventilation. Similar tendencies in changes in the aforementioned indices were observed in calves suffering from specific respiratory diseases, e.g. infection with bovine respiratory syncytial virus [24,25], verminous bronchopneumonia [26], or pneumonia experimentally induced by Pasteurella haemolytica $[27,28]$. Primarily, in all the cases, hypoxia and increased $\mathrm{pCO}_{2}$ values were recorded due to extensive damage to lung parenchyma with post mortem findings of atelectasis, exudative pneumonia, and obstructive purulent bronchiolitis [27]. Although $\mathrm{pO}_{2}$ does not correlate with the clinical picture in all cases, it is an important indicator of disorders in lung diffuse capacity, indicating thus the extent of lung lesions and was considered highly predictive of lesion severity [9,16]. It is suggested that disorders of diffusion and gas distribution are the main cause of hypoxemia $[24,29]$. In animals with marked clinical signs of catarrhal and catarrhalpurulent bronchopneumonia, decrease in $\mathrm{pO}_{2}$ with simultaneous increase in $\mathrm{pCO}_{2}$ in the arterial blood indicates obstructive changes and ventilation disturbances [10]. Obstructive respiratory disorders are of major importance and may result in uneven ventilation distribution and ventilation-perfusion mismatching with hypoxemia, hypoxic vasoconstriction, vascular pulmonary hypertension and in more severe cases hypercapnia [30]. The aforementioned findings are in accordance with our results when increased $\mathrm{pCO}_{2}$ values we recorded mainly in calves with the most severe form of respiratory syndrome.

In all the groups of sick animals, as shown by blood $\mathrm{pH}$ and bicarbonate levels, we did not record values which indicate to acidemia. In most calves with higher $\mathrm{pCO}_{2}$ values due to respiratory diseases, compensated respiratory acidosis was found. This is a compensatory response of the body, when acidemia caused by respiratory disturbances activates secondary physiologic responses that alter the level of plasma bicarbonate. These adaptive changes in plasma bicarbonate concentration pursue a distinct time course and produce readjustments in the acid-base equilibrium that are quantitatively related to the magnitude of the primary change in $\mathrm{pCO}_{2}$ [31]. Adaptation of the renal response begins a few hours after the onset of hypercapnia and lasts several days to achieve maximum efficiency [11,32]. Increase in bicarbonates leads to alleviation of blood $\mathrm{pH}$ changes (acidemia) initiated by increasing $\mathrm{pCO}_{2}$ [33]. In the group of calves with moderate clinical signs, we did not observe blood $\mathrm{pH}$ below 7.35 and in the group with severe signs lower $\mathrm{pH}$ of blood was found only in 4 animals. The highest BE value $18 \mathrm{mmol} / 1$ was recorded in a calf with $\mathrm{pCO}_{2}$ value $10.4 \mathrm{kPa}$ a similar tendency 
of compensation for hypercapnia and respiratory acidosis was observed also in calves, that died within 48 hours after blood sampling. In these calves, however, higher $\mathrm{pCO}_{2}$ values and limited possibilities for hypercapnia compensation were indicated by lower blood $\mathrm{pH}$ values in 7 out of 21 calves with the lowest $\mathrm{pH} 7.17$ and $\mathrm{pCO}_{2}$ value $10.9 \mathrm{kPa}$. Compared with healthy calves, lower blood $\mathrm{pH}$ values in calves suffering from bronchopneumonia are reported also by other authors [23]. Values of $\mathrm{HCO}_{3}^{-}$ and $\mathrm{BE}$ observed in our study corresponded to the dynamics of blood $\mathrm{pH}$. These were significantly higher in calves with severe clinical symptoms. The results confirm that consequences of global respiratory insufficiency affect not only the respiratory system, but also the overall system of acid-base balance.

Respiratory diseases challenge the oxygen transport chain in two ways: a diminished oxygen transfer from the lungs to the arterial blood and an elevated oxygen consumption by increased breathing effort. The relative contribution of the anaerobic pathway becomes more important and, consequently, blood lactate can increase [1]. Because a little is known about the effect of respiratory disease in bovine accompanied by various degrees of hypoxemia on the lactate levels, we analyzed these parameters at the same time with blood gases and compared their relationships. Possible effect of hypoxemia on changes of plasma lactate levels in our study was observed only in calves with severe clinical signs. In group RD 2, we recorded the highest lactate level $2.78 \mathrm{mmol} / \mathrm{l}$. Levels over $2 \mathrm{mmol} / \mathrm{l}$ were found in 3 out of 73 calves. In this group, 46 calves $(63 \%)$ died or were euthanized because of a grave prognosis. Most of these calves showed lactate levels below $1.5 \mathrm{mmol} / \mathrm{l}$. The highest lactate level $8.63 \mathrm{mmol} / \mathrm{l}$ was recorded in the RD 3 group of calves. Levels over $2 \mathrm{mmol} / 1$ were observed in 11 and over $4 \mathrm{mmol} / \mathrm{l}$ in 3 calves. These lactate levels were accompanied by marked hypoxemia with $\mathrm{pO}_{2}$ values 4.4 up to $2.6 \mathrm{kPa}$. A notable relationship between $\mathrm{pO}_{2}$ and lactate values was observed only in severe cases (group $\mathrm{RD} 2$ and $\mathrm{RD} 3$ ), when all the calves with plasma lactate levels over $2 \mathrm{mmol} / 1$ showed $\mathrm{pO}_{2}$ values below 5.5 $\mathrm{kPa}$. These are values when hypoxemia, If pO2 is sufficiently low (less than $5.3 \mathrm{kPa}$ ), hypoxemia can induce lactic acidosis [31]. Similar lactate concentrations in calves suffering from bronchopneumonia are reported during 24 and 48 hours before death [13]. In some of these calves 24 hours before death lactate levels ranged from 11.7 to $22.5 \mathrm{mmol} / \mathrm{l}$. The authors stated that in cases of bovine respiratory disease, a plasma lactate level higher than $4 \mathrm{mmol} / \mathrm{l}$ (measured with the portable analyser) is a reliable prognostic indicator for mortality within 24 hours. Furthermore, our results showed that despite the treatment all the calves with plasma lactate levels over $2 \mathrm{mmol} / \mathrm{l}$ died. We suggest also lactate levels over $1.5 \mathrm{mmo} / \mathrm{l}$ being of high risk as out of 15 observed calves 10 died despite the treatment. Higher plasma lactate was found in calves with bovine respiratory diseases with significantly higher values in calves which died (mean $4.53 \mathrm{mmol} / \mathrm{l}$ ), than recovered (mean $2.15 \mathrm{mmol} / \mathrm{l}$ ) [15]. Another study [16] in calves experimentally infected with bovine respiratory syncytial virus, the arterial blood lactate concentration was significantly associated with lung disease. However, the results were inconsistent for all days after challenge and generally obtained lactate 
levels were within normal reported ranges and values higher than $2 \mathrm{mmol} / \mathrm{l}$ were found only in affected calves with $\mathrm{pO}_{2}$ values lower than $50 \mathrm{mmHg}(6.65 \mathrm{kPa})$. An experimentally induced Mannheimia haemolytica pneumonia successfully yielded clinical signs and pathological effects consistent with the naturally acquired respiratory disease but without a significant increase of lactate concentration [14]. The authors did not find blood lactate concentration to be useful in identifying early BRD, possibly because generalized body-tissue anaerobic metabolism did not have a chance to develop due to the low percentage of pulmonary involvement. Our results indicate higher lactate levels in calves with severe signs of respiratory disease, but these are frequently within the normal range [34-36]. Values over $1.5 \mathrm{mmol} / \mathrm{l}$ are considered risky regarding the prognosis and high proportion of animals, which die later on or must be culled from the herd. Lactate levels over $3-4 \mathrm{mmol} / \mathrm{l}$ indicate a high probability of death within $24-48$ hours [13]. About the aforementioned studies, it is obvious that the evaluation of the effects of respiratory diseases on blood lactate levels is not uniform. In spontaneous bovine respiratory disease or enzootic bronchopneumonia, there were higher concentrations than in experimental cases with selected pathogens. This may result from the complexity of the disease etiology and pathogenesis, extent and severity of respiratory affections and, partially, from different samples and methods of lactate analysis (venous or arterial whole blood, blood plasma, blood chemistry analyzers, portable analyzers, enzymatic-photometric or amperometric methods). Therefore, further investigations are needed to evaluate the use of blood lactate measurements and clearance in bovine respiratory diseases.

In conclusion, in this study we evaluated respiratory diseases in calves trough a complex of indices, which included not only blood gases $-\mathrm{pO}_{2}$ and $\mathrm{pCO}_{2}$ per se, but also $\mathrm{pH}$ and metabolic indices of acid-base balance ( $\mathrm{HCO}_{3}{ }^{-}$and $\mathrm{BE}$ ). In addition, we evaluated the relations between hypoxemia and lactate production. In calves suffering from respiratory diseases, our results indicate marked changes in lung functions, which correlate with the severity of clinical symptoms. While in moderate clinical symptoms we observed a mainly partial respiratory insufficiency characterized by hypoxemia and lower saturation of haemoglobin with oxygen, severe clinical symptoms were accompanied by global respiratory insufficiency, marked hypoxemia and hypercapnia. In most cases, respiratory acidosis and hypercapnia in calves did not lead to a decrease in blood $\mathrm{pH}$ and acidemia. In calves with hypercapnia, blood $\mathrm{pH}$ ranged within the normal values or higher, thus reflecting a metabolic compensation of the primary respiratory disturbance in acid-base balance. In these calves we recorded higher values of $\mathrm{HCO}_{3}^{-}$and $\mathrm{BE}$. Expected effects of hypoxemia and reduced tissue oxygenation on the increase in plasma lactate levels and possible changes in blood $\mathrm{pH}$ were recorded only in some sick calves shortly before death. According to the presented results, analysis of blood gases and acid-base balance represents an important diagnostic tool, which may supplement the clinical findings in the evaluation of the extent and severity of lung functional disorders, estimation of prognosis, and adopting treatment. On the other hand, the use of lactate analysis is quite limited and it seems to be useful 
mainly in severe cases with marked clinical signs, when lactate levels over $2.00 \mathrm{mmol} / \mathrm{l}$ indicate a poor prognosis and/or forthcoming death of the animal.

\section{Acknowledgements}

This work was supported by VEGA Scientific Grants No. 1/0154/15 and 1/0447/14 from the Ministry of Education.

\section{REFERENCES}

1. Coghe J, Uysterpruyst Ch, Bureau F, Van de Weerdt ML, Lekeux P: Preliminary classification of the bovine respiratory complex into different levels of severity. Bovine Pract 1999, 33:85-87.

2. Andrews GA, Kennedy GA: Respiratory diagnostic pathology. Vet Clin N Am - Food Anim Pract 1997, 13:515-547.

3. Pringle JK: Ancillary testing for the ruminant respiratory system. Vet Clin North Am Food Anim Pract 1992, 8:243-256.

4. Dirksen G, Stöber M: Ursachen von Misserfolgen bei der Behandlung der enzootischen Bronchopneumonie des Rindes. Prakt Tierarzt Coll Vet XII 1981, 63:104-112.

5. Bryson DG: Calf pneumonia. Vet Clin North Am - Food Anim Pract 1985, 1:237-257.

6. Collie DDS: Pulmonary function changes and clinical findings associated with chronic respiratory disease in calves. Brit Vet J 1992, 148:33-40.

7. Reinhold P, Födisch G: Lungenfunktiondiagnostik bei gesunden und an Pneumonie erkrankten Kälbern. Mh Vet-Med 1993, 48:113-117.

8. Calderwood HW: Clinical Application of Blood Gas Analysis and pH Measurements in Veterinary Practice. J Am Anim Hosp Assoc 1972, 8:444-447.

9. Scholz H, Currle M, Fischer W: Untersuchungen zur Bronchopneumonie des Rindes. 2. Mitteilung: Endoskopische, Tracheobronchialsekret - und Blutgasuntersuchungen. Tierärztl Umschau 1987, 42:371-378.

10. Schäfer M, Paentzer S, Uhling A: Klinische Formen der enzootischen Pneumonie bei Kälbern und ihre Auswirkungen auf die Atmung. Dtsch Tierärztl Wschr 1992, 99:200-204.

11. Deegen E: Beurteilung von Blutgasparametern des arteriellen Blutes bei Pferden mit respiratorischen und metabolischen Störungen. Prakt Tierarzt Coll Vet XIV 1983, 65:128132.

12. Hendricks JC: Respiratory Conditions in Critical Patiens. Vet Clin North Am - Small Anim Pract 1989, 19:1167-1188.

13. Coghe J, Uysterpruyst Ch, Bureau F, Detilleux J, Art T, Lekeux P: Validation and prognostic value of plasma lactate measurement in bovine respiratory disease. Vet J 2000, 160:139-146.

14. Hanzlicek GA, White BJ, Mosier D, Renter DG, Anderson DE: Serial evaluation of physiologic, pathological, and behavioral changes related to disease progression of experimentally induced Mannheimia haemolytica pneumonia in postweaned calves. Am J Vet Res 2010, 71:359-369.

15. Camkerten I, Borku MK, Kalinbacak A, Borazan GO, Sahin T, Aktas MS: Clinical utility of lactate in calves with bovine respiratory disease. J Anim Vet Advances 2010, 9:1955-1957.

16. Ellis J, Waldner Ch, Gow S, Jackson M: Relationship of the extent of pulmonary lesions to the partial pressure of oxygen and the lactate concentration in arterial blood in calves 
experimentally infected with bovine respiratory syncytial virus. Can J Vet Res 2013, 77:205210.

17. Jackson PGG, Cockcroft PD: Clinical examination of farm animals. Blackwell Science Ltd., Oxford, United Kingdom, Blackwell Publishing Company; 2002, 1-112.

18. Kirschwink N: Respiratory function in cattle: impact of breed, heritability and external factors. Dtsch Tierärztl Wschr 2008, 115:265-270.

19. Eltze K, Selbitz HJ: Differential diagnosis, treatment and prevention of respiratory diseases of calves. Tierärztl Umschau 1993, 48:581-587.

20. Proulx J: Respiratory monitoring: arterial blood gas analysis, pulse oximetry, and end-tidal carbon dioxide analysis. Clin Tech Small Anim Pract 1999, 14:227-230.

21. Reinhold P: Physiological and pathophysiological aspects of respiratory function in the bovine species. Tierärztl Umschau 1997, 52:584-592.

22. Reinhold P, Höchel P: Pathophysiological consequences of airway and lung diseases on pulmonary circulation. Berl Münch Tierärztl Wschr 2005, 118:52-56.

23. Vestweber GE, Guffy M, Kelly B, Leipold HW: Chronic bronchopneumonia in cattle. Bovine Pract 1977, 12:55-62.

24. Lekeux P, Verhoeff J, Hajer R, Breukink HJ: Respiratory syncytial virus pneumonia in Friesian calves: physiological findings. Research in Veterinary Sciences 1985, 39:324-327.

25. Verhoeff J, Wierda A, van Nieuwstadt AP, Buitelaar JW: Spontaneous bovine respiratory syncytial virus infections in calves: Arterial blood gas, $\mathrm{pH}$ and bicarbonate values. Vet Rec 1985, 117:202-204.

26. Lekeux P, Hajer R, Breukink HJ: Longitudinal study of the effects of lungworm infection on bovine pulmonary function. Am J Vet Res 1985, 46:1392-1395.

27. Slocombe RF, Derksen FJ, Robinson NE: Interactions of cold stress and Pasteurella haemolytica in the pathogenesis of pneumonic pasteurellosis in in calves: Changes in pulnonary function. Am J Vet Res 1984, 45:1764-1771.

28. Alnoor SA, Slocombe RF, Derksen FJ, Robinson NE: Hemodynamic effects of acute pneumonia experimentally induced in newborn calves inoculated with Pasteurella haemolytica. Am J Vet Res 1986, 47:1382-1386.

29. Verhoeff J, Cruijsen ALM, Kremer WDJ: Mismatching of ventilation and perfusion in calves with natural bovine respiratory syntitial virus infection. Vet Rec 1988, 123:131-134.

30. Lekeux P, Art T, Hamoir J, Gustin P: Pathophysiology of the respiratory tract. In: Dunlop RH, Malbert CH-H: Veterinary pathophysiology. Blackwell Publishing Ltd; 2004, 143-173.

31. Madias NE, Cohen JJ: Respiratory alkalosis and acidosis. In: Seldin DW, Giebisch G: The Kidney: Physiology and Pathophysiology, Raven Press, Ltd, New York, 1992, 2837-2872.

32. Orsini JA: Pathophysiology, diagnosis, and treatment of clinical acid-base disorders. Comp Cont Educ Pract Vet 1989, 11:593-604.

33. Chew DJ, Kohn CW: Disorders in acid-base balance. In: Fenner WR: Quick reference to veterinary medicine. JB Lippincott Company, Philadelphia, 1991, 613-622

34. Lagutchik MS, Ogilvie GK, Wingfield WE, Hackett TB: Lactate kinetics in veterinary critical care: A review. J Vet Emerg Crit Care 1996, 6:81-95.

35. Tóthová C, Nagy O, Kováč G: The serum protein electrophoretic pattern and acute phase proteins concentrations in calves with chronic respiratory diseases. Acta Vet-Beograd 2013, 63(5-6): 473-486.

36. Stojanović D, Kovačević Z, Žekić M, Ašanin J, Ratajac R, Petrović J, Petrović T, Stojanov I, Velhner M: Examination of enzymes concentration in the blood of rats with sepsis caused by mixed and pure bacterial cultures. Acta Vet-Beograd 2013, 63(5-6):609-620. 


\title{
GASOVI U KRVI, ACIDO-BAZN I STATUS I KONCENT RACIJE LAKTATA U PLAZMI KOD TELADI SA RESPIRATORN IM OBOLJENJIMA
}

\author{
ŠOLTÉSOVÁ Helena, NAGY Oskar, TÓTHOVÁ Csilla, PAULÍKOVÁ Iveta, \\ SEIDEL Herber
}

Cilj studije je bila evaluacija efekata respiratornih oboljenja različite težine simptoma na gasove u krvi, acido-baznu ravnotežu, kao i na koncentraciju laktata u plazmi kod teladi. Studijom je obuhvaćeno 128 teladi, starosti 1 do 12 meseci koja su imala respiratorna oboljenja različita po intenzitetu kliničkih simptoma i ishodu bolesti. Prema kliničkom nalazu, toku bolesti i vremenu sakupljanja krvi, životinje su podeljene u tri grupe: RD 1 ( $n=34)$ grupa je imala srednje izražene kliničke simptome, RD 2 ( $n=73$ ) grupu su činila telad sa snažno izraženim kliničkim simptomima i RD 3 (n=21) grupu, telad sa izraženim simptomima koja su uginula 48 sati posle uzimanja uzorka krvi. U okviru studije, nalazila se i kontrolna grupa $(n=28)$ klinički zdravih teladi. $U$ arterijskoj krvi mereni su sledeći parametri: $\mathrm{pH}$, parcijalni pritisak ugljen dioksida (pCO2), parcijalni pritisak kiseonika (pO2), koncentracija stvarnog bikarbonata (HCO3-), višak baza (BE) i saturacija hemoglobina kiseonikom (O2-sat). U plazmi je merena koncentracija laktata. Značajni efekti na zdravstveni status i izraženost kliničkih respiratornih simptoma uočeni su u odnosu na sve parametre koji su ispitivani. Naglašena hipoksemija i hiperkapnija su uočene kod teladi sa teškim simptomima, kao i kod životinja koje su uginule u roku od 48 sati nakon uzimanja uzorka krvi. Kod većine teladi, acido-bazni poremećaji su se tumačili kao kompenzacija respiratorne acidoze. Najveća prosečna koncentracija laktata uočena je kod teladi koja su uginula u roku od 48 sati od uzimanja uzorka krvi. Prikazani rezultati ukazuju na značaj analize gasova krvi kao i acido-baznog statusa prilikom evaluacije i davanja prognoze kod respiratornih oboljenja teladi različitog intenziteta kliničkih simptoma, kao i kod praćenja uspeha primenjene terapije. Iako su koncentracije laktata bile manje u skladu sa izraženim simptomima, ovaj parametar ipak može da bude od pomoći prilikom procenjivanja faze bolesti u kojoj lečenje nije moguće, kao i kod prognoze fatalnog ishoda. 